\title{
SUPERHEROES: MYTHS OF MODERN AGE?
}

\author{
Büşra HAFÇI ${ }^{1}$, Gül ERBAY ASLITÜRK ${ }^{2}$
}

\begin{abstract}
People in ancient Greece and Rome created their own heroes as leaders and believed in them. These stories passed on by word of mouth, and thanks to Iliad and Odessa by Homer, they were then written down. Even planets and star clusters are named after the gods of Rome, and even words we use regularly, such as "echo," "erotic," "chaos", and "volcano" originate from Greek myths. Mythology is an abstract power that ties people and cultures. Our understanding of 'hero' also comes from Greeks and Romes. As a result of globalization, the world gets more complex and stories change form and content to keep up with their complexity. Today's brilliant concept is to replace those myths and call them "super heroes". These heroes first appeared in comic strips by Marvel Comics and then they were presented as films. Thus, super heroes became worldwide known. The aim of this study is to find out common points of worldwide famous super heroes and their roots in ancients myths. The Avengers film series of Marvel Comics is to be analyzed via content analysis method. There are two ways of applying myths to cinema. First method is to make a film out of a myth directly and the second method is to incorporate ancient myths in contemporary films. Since The Avengers film series uses both of these methods, it seems to be able to represent the myths very strongly. To strengthen the evaluations, Captain America, Hulk, Iron Man, and Thor film series are also analyzed as these characters are part of The Avengers. At first, mythology and its relation with popular culture is mentioned and secondly The Avengers film series is examined in a detailed way.
\end{abstract}

Key Words: Greek Mythology, Super Hero, Marvel, The Avengers.

Hafç1, Büşra., Erbay Aslitürk, Gül., "Superheroes: Myths Of Modern Age?". idil 6.30 (2017): 497-510.

Hafçı, B., Erbay Aslıtürk, G., (2017). Superheroes: Myths Of Modern Age?. idil, 6 (30), s.497-510.

\footnotetext{
${ }^{1}$ Okt. Büşra Hafçı- İngilize Okutmanı, Adnan Menderes Üniversitesi, Turizm Fakültesi, busrahafci(at)adu.edu.tr tr

${ }^{2}$ Yrd. Doç. Dr.-Sanat Tarihçi, Adnan Menderes Üniversitesi, Turizm Fakültesi, Turizm Rehberliği Bölümü, gerbay(at)adu.edu.
} 


\title{
SÜPER KAHRAMANLAR, MODERN ÇAĞIN MITLERI MIDIR?
}

\begin{abstract}
ÖZ
Eski Yunan ve Roma'da insanlar kendilerine önderlik edebilecek, güçlü kahramanlar oluşturup onlara inanmışlardır. Bu hikâyeler ağızdan ağza yayılmış ve ayrıca da Homeros'un, İlyada ve Odesa destanları ile yazılı geleneğe dönüşmüştür. Gezegenler, takımyıldızları bile isimlerini tanrılardan almaktadır. Hatta günlük hayatta bile kullanılan "echo", "erothic", "chaos", "volcano" gibi kelimeler mitolojik kökenden gelmektedir. "Kahraman" algımızda bile Roma ve Yunan izlerine rastlamak mümkündür. Küreselleşmenin bir sonucu olarak sınırlar ortadan kalktıkça, mesafeler kısaldıkça, kültürler de birbirine çok yaklaşmış ve böylelikle kahramanlar yalnızca bir halkın değil bütün insanlığın kültürel varlığı haline gelmiştir. Mitoloji, insanoğlunun yaşam tecrübesine dayanan soyut bir bağdaştırıcı güçtür. Mitolojik hikâyeler, hayatın karmaşık bir yapı almasına ayak uydurarak varlıklarını sürdürmüşlerdir. İnsanların yaşamları, tecrübeleri ve eğlence anlayışları değiştikçe, eski mitler onların ilgisini çekmeyebilir, günümüzde mitlerin yerini alabilecek muazzam kavram ise "Süper Kahraman"dır. Bu kahramanlar, ilk olarak Marvel Comics tarafından çizgi roman türünde, ardından sinemaya uyarlanarak insanlara sunulmuştur. Böylelikle süper kahramanlar dünyaca tanınan modern çağın mitosları biçimini almıştır.Bu çalışmanın amacı, tüm dünyaca benimsenen Süper Kahraman kavramının kökenlerinin tarihi mitlerle ortak yönlerini tespit etmektir. Bunun için, Marvel Comics'e ait The Avengers (Yenilmezler) film serisi içerik analizi yönteminden faydalanılarak çözümlenecektir. Mitolojik hikâyeleri sinemaya uyarlamanın başlıca iki yöntemi vardır; mitolojik hikâyenin doğrudan filmi çekilebilir veya modern bir metnin içine hikâye uyarlanabilir. The Avengers (Yenilmezler) film serisi, her iki yöntemi de kullandığ için temsil yeteneğinin güçlü olduğu düşünülmüştür. Aynı zamanda, değerlendirmeleri güçlendirmek adına kendi isimleriyle film serilerine sahip olan The Avengers (Yenilmezler) karakterleri; Captain America (Kaptan Amerika), Hulk, Iron Man (Demir Adam) ve Thor film serileri de içerik analizi yöntemi ile incelenmiştir. İlk olarak mitoloji ve popüler kültürdeki mitolojiden, ardından da Marvel Comics'in yarattığı The Avengers (Yenilmezler) film serisinden yola çıkılarak, süper kahramanların kökenlerini oluşturan tarihi mitlerle benzerliklerine değinilecektir.
\end{abstract}

Anahtar Kelimeler: Yunan mitolojisi, Süper Kahraman, Marvel, Yenilmezler 


\section{INTRODUCTION: MYTHOLOGY, FICTION OR FACT?}

Making sense of the world is the prime condition of man's existence. Mankind writes his own story by giving the meaning and reshaping the outside world. Myths offer great contributions to making sense of human history: According to Barthes (1975; 109), a myth is a way of communication, a message. It reminds us that a myth is not an object, a concept or an idea, but a way of making sense. Myths on which social consciousness is based also provide the inner world of mankind to meet the outside world. Mythological fiction reflects the way societies perceive reality, while at the same time mythological symbols have an important place in the production of social reality. Social consciousness is only embodied in social practices, and therefore mythology is intertwined with these practices (Shepherd, 2016). According to Mullen (1998, p. 48), in modern culture, myths have adapted themselves to cultural actors of the societies they lived so well that we almost cannot perceive them as myths. Myths are the soul of the society as well as being the memory of it: "The societies that protect myths and keep them alive are nourished by the strongest feature of the human soul" (Campbell, 1972, 14-5).

It is possible to interpret a society's psychology and subconscious through myths (Eliade, 1992, XIX). All facts in life, especially life and death, are the subjects of myths. Myths have the mystery of man's existence and at the same time they represent the first products of artistic production, forming the starting point of artistic narratives coming after them; "Myth, your seeds of the future will overflow; It uses these literary forms of the creative genius of the peoples and the conscious art of civilization" (Malinowski, 2000, 147).

Myths that reappear in an artistic scene trigger social changes. The mass media provides myths effectively for the use of modern age societies. In shaping the consciousness of society, today's sociological and cultural changes have a major role (McCloud, 1993). Along with these developments, mythology redefines itself according to the concrete conditions, shapes the society and begins to process the developments as a part of the process. In this context, cinema is under the influence of mythology as one of the most effective forms of art in the cultural field. All cultural elements form the same socio-cultural frame undergo the production process under the influence of each other.

\section{MYTHS AND CINEMA IN POPULAR CULTURE}

It is evident that myths can sustain their existence throughout history, and that myths are a profound necessity for people. With the advancement of technology and the increase of intercultural interaction, myths have begun to diversify, to spread, 
and have become the center of societies. Many myths, which people are most curious about and which involve the efforts of making sense of life, have always had an important place for societies. Mythos was also described by Walter Burkert (1982) as "a coherent story, a traditional story found in particular sentences". At the center of these common phenomena is the myth that each individual associates with his/her own life under the consciousness. Mythological heroes can originate from seemingly impossible events. Myths that are called as "hero myth" differentiate from human beings with their supernatural powers. At the same time, these heroes seem to be adapted to the culture they are in, in terms of their social and sociological situation and their emotions. Motion pictures based on hypothetical mythology, series films, comics are among the most important evidence of the present existence of myths. However, mythological heroes have undergone a change over the past. The main reason for this is the complex life that globalization and technology bring together. Mankind can no longer live as lean as the old man. For this reason, the superhero sensation is also visually more complex.

Through the art of cinema, myths continue to be introduced into societies. Myths can be used for forgetting, escaping, pleasure, as well as for recalling, awareness and difference. Ultimately, cinema is a fantasy world that provides people with effective possibilities in terms of understanding their own reality (Shepherd, 2016). The myths conveyed to the new generation represent the imagination of that society while legends constitute the verbal memory of a society. (McCloud, 1993). The myths about Creation, Gods and heroes are the basic classes of mythology and it is possible to find common stories among them. Given the concept of "Monomyth", which Joseph Campbell (2008) mentions in the book "The Mask of God" that all of the heroes are based on common ground, it is possible to say that myths have had similar effects on humans for centuries. Although the events that mythological heroes who have been subjected to evolution over time seem to be different, the resulting patterns and events are quite similar to each other. Their adventures resemble the idealized and exaggerated expression of the results that people experience in their lifetime (Barthes, 1975: 109). In this sense, superheroes can be said to be modern monomyths that can appeal to the imagination.

The pioneers of modern superheroes are comic series. "With the simplest definition, words and photographs with chronological order that do or do not have humor in comics are the whole" (McCloud, 1993). Comics first appeared in America in the 1800 's, based on visual and daily language use, without concern for detailed information about the heroes. From the 1960's onwards, there are two major companies, Marvel Comics and Detective Comics (DC), which produce superhero books. Marvel Comics is named as Timely Comics between 1939-1950 and Atlas Comics in the 1950's. It can be said that Marvel Comics is a bit closer to the fan base 
when it comes to its development over time. Just like in the field of literature, the fans call the processes of Marvel Comics as "period", and the Golden Age from 1939 to 1956, the Silver Age from 1956 to 1971, the Bronze Age from 1971 to 1980, the Iron Age from 1980 to 1987, and the modern age (Reidelbach, M. 1991). Marvel Comics is one of the companies that carries mythology into today most effectively. The founder of the company, Martin Goodman, was a publisher of superhero stories. Contrary to the popular comic book movement, he created Superman that is the first mythological superhero published by the company, and thus he started the era referred to as the golden age in comic book history. In the modern age, the superhero concept can be described as a phenomenon that has supernatural powers but is so close to the spectator. Superman character is a popular cul-de-sac feature of being the first mythological hero. In the modern age, the superhero concept can be described as a phenomenon that has supernatural powers but is so close to the spectator. From that first step to today, Marvel Comics has incorporated over 8000 superheroes with mythological similarities, even though they have changed names or forms.

While mythology is being transmitted through cinema, the mythological story can be filmed directly or the mythological story can be adapted into a contemporary text. The myths that fit the hero's myth are the Black Widow, Captain America, Hawkeye, Hulk, Iron Man, Loki, Nick Fury and Thor with the characters of The Avengers movie.

There are more than 8000 characters in Marvel Comics, but it is not possible in this work to handle each character individually because there are too many. However, the film series The Avengers, was created by bringing together popular superheroes like Black Widow, Captain America, Hawkeye, Hulk, Iron Man, Loki, Nick Fury and Thor. It is an important work of Marvel Comics. At the same time, the work stands out as a powerful representation in which it uses two ways to adapt mythological stories to cinema. For example, Thor from the characters in the film is a mythological character while Iron Man represents a mythological character adapted to modern texts. For these reasons, it is important to study these individual characters and examine their power to represent mythological characters. The heroes of The Avengers are handled in alphabetical order.

\section{BLACK WIDOW}

Black Widow appears in the first film of The Avengers, but is not part of the team at first. She is a Russian agent. She is convinced by Nick Fury to join The Avengers team SHIELD (Supreme Headquarters International Espionage Law Enforcement Division) (Miller, 1997). 
While she is a Russian agent, she portrays a very strong female fighter character in The Avengers. She has had extensive training in martial arts. From this, it is possible to say that it reminds the goddess Athena in Greek mythology. Athena is Zeus's favorite child and a highly successful female character in martial arts. She is a goddess who uses her intelligence very well and is known for her just nature. Athena can be seen as a ruthless goddess in Greek mythology, but it is also possible to link her ruthlessness to her sense of justice (Erhat, 1987).

Black Widow and Athena can be likened to each other not only for their fighting but also for their intelligence. In a scene of The Avengers, Black Widow saves herself using her intelligence without using force. (Miller, 1997) Another similarity is that Athena and Black Widow are never married and have no children. When we make an assessment in this point of view, both women might try to connect the masculine traits of being strong, not having children and not bringing femininity the foreground.

\section{CAPTAIN AMERICA}

Captain America character also has a movie series made up of his own name, and the characters that appear in the first film of this series are actually ordinary people. In the movie, Captain America takes a super powerful drug and gains special powers like semi-gods. (Johnston, J. 2011: Captain America) This actually reminds us Perseus of the Greek God.

Perseus was not a god at first but other gods empowered him with gifts and special powers. On the other hand, the most important task of Perseus was to cut off Medusa's head because everybody who looked at Medusa's head turned into stone. In order to protect all people from this danger, Medusa's head had to be cut off and this duty belonged to Perseus. Perseus succeeded decapitating Medusa using his shield (Kozanoğlu, M. 1992). When this scene in Greek mythology is assessed for Captain America, the first of the film series The Avengers has to face and destroy the powerful enemy Red Skull, which threatens the humanity. Otherwise humanity may disappear. It is possible to say that Red Skull represents modern Medusa by establishing a link between Red Skull and Medusa. On the other hand, Perseus and Captain America have a shield, and this shield is the most important tool they use to defeat their enemies.

In terms of the similarities of Captain America and Perseus, it is worth considering a sentence established by Captain America in The Avengers: "We have to save as many people as we can. This may not mean that we can save everybody, but if we do not find a way to live with it, it may mean that we cannot save anybody." This 
sentence was without doubt that if Greek mythology had been spoken by God Perseus, it meant destroying Medusa. Without doubt, in The Avengers, Captain America, is referring to Red Skull by those words, which can be interpreted as modern Medusa.

\section{HAWKEYE}

The Hawkeye superhero in The Avengers, is a superhero who gets confused in the film series. He has improved himself very much in archery and has been using his skill very well as a battle art. A good connection between talent in archery and the Greek God Apollon can be established. The Greek god Apollon is also very good at archery and is also known as a silver bow master (Erhat, 1987). Hawkeye also designed his own bow and this bow is a piece of the superhero.

Hawkeye, as well as the ability to use arrows as a superpower can also refer to Artemis. Artemis is the twin brother of Apollon and is very good at using arrows. Besides, Hawkeye is a superhero who spent his childhood in an orphanage. It can be said that he did not spend his child very happily. Artemis killed Niobe's children along with his brother Apollon because Niobe had fourteen children, seven girls and seven boys, and Apollon and Artemis's mother wanted to make Leto jealous (Erhat, 1987). In this regard, while Hawkeye was raised without his mother, Apollon and Artemis made sacrifices for their mothers. This can be regarded as a difference.

\section{HULK}

It is possible to compare the green giant Hulk of the film series The Avengers to Hades from the famous gods of Greek mythology. Hulk is not actually a green giant, but lives in an ordinary human body, but when he gets angry he gets a monster look, he becomes unrecognizable. Mythological God Hades is a god who can be extremely bad when he is angry. Surely, it is no coincidence that both of them live an isolated, lonely life.

It is quite possible to compare the modern-day superhero Hulk to Hercules in spite of the monster-like appearance. Hercules is the son of Hera, and his mother's enmity toward him, caused his childhood to be not so bright. Hera even tried to kill him (Vitterso, J. et al., 2010: 1-18). Hulk had a bad childhood because of his father. His father, at the beginning of the film series Hulk, succeeds in defeating Hulk and kills his mother (Lee, A., et al., 2003: Hulk). Looking on their adulthood, they both set up a family. But around them, they are envied, and this caused both Hulk and Hercules to lose their families. Hera caused Hercules to pierce and kill his own family. Hulk lost his wife because of the effect of a radioactive substance emitted by the enemy character Abomination (Lee, A., et al., 2003: Hulk). 
Another common aspect of Hulk and Hercules is their ability to work in harmony with the team they are in. Hercules has survived a series of adventures without any damage with his team. Hulk later joined The Avengers team and is helping the intended people to do so. Both of them are able to help around the basic purpose.

There are also aspects that distinguish Hulk and Hercules from each other. Hercules was born as a mortal, but as a result of his adventures he was presented with immortality. Hulk, on the other hand, is a form and a mortal that changes shape when angry. Another noteworthy difference is that Hercules is loved by everyone. It is also possible to say that Hercules and Hulk are unloved and undesirable characters around.

\section{IRON MAN}

Iron Man is on the forefront both in his film series and in The Avengers film series. Iron symbolically resembles the Greek God Hephaestus. God Hephaestus is a master of iron, also known as the god of fire, who can shape it for martial arts, which can be said to be parallel to the Iron Man's heroic use of martial arts and even to the firing of his eyes (Favreau, J.). Another similarity is that Iron Man uses his special costume to fly, which draws another similarity with Hephaestus since he is a master in using iron in a special way, even in Iliad, he was mentioned as "the god preparing the weapons and armor of all immortals".

Another similarity is that Hephaestus married Aphrodite, the most gorgeous Greek goddess, and Iron Man is not married but always surrounded by beautiful women. The main reason for this is that the Iron Man character is a visually handsome superhero. But at this point, an important difference between Iron Man and Hephaestus is striking. While Iron Man is a very handsome superhero, Hephaestus is not a visually appealing god, being lame the main reason.

\section{LOKI}

Loki is the half-brother of God Thor, in Scandinavian mythology. Odin killed Loki's father and adopted him, but Loki never took it well. Odin valued Thor the most and made him the prime of Asgard. Loki is jealous of Odin for Thor receiving so much value, and is also known as god of evils. (Orchad, 1997)

Superhero Loki is very jealous of Thor and therefore always makes mistakes. It is not possible to mention that he is a bad character, because Loki knowingly makes many mistakes every time he tries to make up for his mistake. The only mistake he 
cannot compensate is to lead Ragnarok*. The film has an important difference and contradicts to the myth that Thor and Loki look like biological siblings.

*Ragnarok: Doomsday in Scandinavian mythology.

\section{NICK FURY}

Nick Fury is a never superhero of the Avengers team. From this point of view, it may not be possible to compare it to any characters in mythology, but it is quite possible to compare the character of Nick Fury to that of the Corinthian Calchas when considered more carefully. Oracle Calchas had anticipated the Trojan War, which had a very important place in Homer's Iliad, and convinced the gods to join the war. Nick Fury has predicted a war that will shake the world, and has convinced The Avengers to get their superheroes together.

\section{THOR}

In the Scandinavian mythology, Thor is a god living in a supernatural place named Asgard. His father, Odin, directs Asgard and asks one day to have a son who can hardly beat himself. So he convinces Gaea, the goddess of the earth, and Thor is born in a small cave in Norway. Odin takes his wife to Frigga, to Asgard. Because Thor was born on earth, it can be said that he resembles a human more than a god. On his eighth birthday his father, Odin, makes him the famous charmer named "Mjolnir", which can be a powerful weapon, but he will present it as a gift when Thor proves himself in battle. So, in the next eight years, Thor receives military training. Odin presents Mjolnir as a gift to Thor after he is sure of his success in this area, and proclaims him the most magnificent warrior of Asgard (D'aulaire, I., \& d'Aulaire, 1967).

Thor, which we encounter in popular culture, is the lightning god of Scandinavian mythology, between Marvel Comics superheroes. With design differences from first appearance, it appeared as a side character in the 11th of Venus comic book in 1950. Then in 1962, Journey into Mystery appeared as the main character in the final $\left(83^{\text {rd }}\right)$ design. Just as it is in mythology, he is the son of Odin and the prince of Asgard and his weapon is the magic hammer Mjolnir. According to the comic book, Ragnarok came to the scene many times and the gods are reborn. Thor finally stops this cycle and brings Asgard and his compatriots to the world.

In Thor's film, Odin sends him to the world as part of his education. Thor comes to the world as a medical student named Donald Blake and graduates from this school under this identity. Then, working life begins, but in this process various 
adventures are taken to save the world and help humanity. Since Thor is a god in mythology, it is not necessary to consider similarities with Thor from Marvel Comics, but it would be useful to examine their differences.

Described in mythology, Thor is a red-haired bearded prince. Thor who appears in film, is a blue-eyed, blonde character with a beard. It may be possible to connect these visually different characters to the strong and beautiful male structure of the past and present. In the past, while the beard in the strong male representation was the forerunner, today the beard shave is strong and can display a beautiful male image. It is also possible to link this difference to the current "Scandinavian" perception. Thor mythology is also Scandinavian in the film. In the modern era, it is possible to say that the blond, blue-eyed face structure revives Scandinavian in the minds of people. Another difference in the film is that Thor does not need any special tools to use Mjolnir, whereas the mythological God Thor must wear his magic glove to use Mjonlir. On the other hand, while there was a god Thor (Branagah, K. 2011: Thor) sent to the world by his father in the film, his father in mythology never sent him to the world. While God Thor is able to fly whenever he wants, the superhero Thor is not being portrayed with his flying ability. In addition, the mythological god Thor is married to Sif, a goddess, but the film's superhero Thor, loves a mortal named Jane Foster.

\section{CONCLUSION}

Myths are one of the oldest values of society. It is possible to find traces even in our day, since they are subconscious sides of people. With the development and possibilities of technology, myths have found a chance to emerge in modern life. One of the most important reflections of this is comic strips and film series which follow. Marvel Comics now has more than 8000 superheroes bearing mythological traces. In the film series The Avengers, where detailed analysis of the content was carried out within the scope of the study, the superheroes were compared to gods, especially the gods of Greek mythology (Table 1). It can be said that the supernatural abilities of superheroes are usually based on war strategies. In Greek mythology, the use of instruments such as bone, arrow, bow, and iron on battleground are the most remarkable aspects in the superhero characteristics. Examples include the ability of Iron Man and Hephaestus to use iron as a demon combat weapon, Hawkeye, Artemis and Apollon using archery skills. At the same time, the mythological gods and the enemies that superheroes fight against are also common. The most important example that can be given is Red Skull, the enemy of Captain America, and Medusa, the enemy of Perseus. In short, the concept of "war" in superheroes is originating from mythological sources. On the other hand, another feature paralleling mythology is that the feelings of superheroes are similar to those of mythological gods. Superheroes 
such as Loki and Hulk seem to share the same fate with mythological gods in unfortunate events in their childhood. The love lives of superheroes resemble the emotional relationships of mythological gods in many ways, even if they break up at some point. An example of this is the similarity between Black Widow and Athena.

It is possible to say that the most important difference between superheroes and mythological gods is mainly their physical appearance. The appearance of superheroes, which resemble mythological gods in many ways, has changed in parallel with the changing sense of power and beauty in modern society. It is not possible to find God Thor as red-haired and beardless but instead a bearded blond superhero Thor: both represent power and beauty.

In light of all these inferences, today's superheroes are quite similar to the ancient mythological gods and Greek mythology, and have changed over time, penetrating into all parts of the global societies through cinema culture.

\section{RESOURCES}

Barthes, R. (1975). Mythologies. Hill and Wang, New York.

Branagah, K. (2011). Thor (film). Paramount Pictures.

Burkert, W. (1982). Structure and history in Greek mythology and ritual (No. 47). University of California Press.

Campbell, J. (1972). Myths to Live By. Viking Press, New York

Campbell, J. (2008). The hero with a thousand faces (Vol. 17). New World Library.

Çoban, B.(2016). Sinema, Mitoloji, İdeoloji.

D'aulaire, I., \& d'Aulaire, E. P. (1967). Norse gods and giants. Doubleday Books.

Erhat, A. (1984). Mitoloji sözlüğü (Vol. 18). Remzi Kitabevi.

Favreau, J., Downey, R., Paltrow, G., Cheadle, D., \& Theroux, J. (2010). Iron man 2 (film). Concorde Home Entertainment.

Johnston, J. (2011). Captain America (film).Paramount Pictures.

Kozanoğlu, M. T. (1992). Yunan mitolojisi. Mitologya. 
Lee, A., Kirby, J., Connelly, J., Elliott, S., Lucas, J., Nolte, N., \& Machine, G. (2003). Hulk (film). Hollywood: Universal Pictures.

Levi-Strauss, C. (1983). Din ve Büyü. Yol Y, İstanbul.

Malinowski, J. M., \& Bolesta, S. (2000). Rosiglitazone in the treatment of type 2 diabetes mellitus: a critical review. Clinical therapeutics, 22(10), 1151-1168.

McCloud, S. (1993). Understanding comics: The invisible art. Northampton, Mass.

Miller, T. (1997). The avengers. British Film Institute.

Mullen, L. (1998) Truth In Photography: Perception, Myth And Reality In The Postmodern World.

Orchad, A. (1997). Dictionary of Norse Myth and Legend, Cassell Press.

Reidelbach, M. (1991). Completely Mad: A history of the comic book and magazine. Boston: Little, Brown.

Vittersø, J., Søholt, Y., Hetland, A., Thoresen, I. A., \& Røysamb, E. (2010). Was Hercules happy? Some answers from a functional model of human well-being. Social Indicators Research, 95(1), 1. 


\begin{tabular}{|c|c|c|c|}
\hline $\begin{array}{l}\text { SUPER } \\
\text { HERO }\end{array}$ & $\begin{array}{l}\text { MYTHOLOGICAL } \\
\text { HEROES/GODS/GO } \\
\text { DDESSES }\end{array}$ & SIMILARITIES & $\begin{array}{l}\text { DIFFERENCE } \\
\text { S }\end{array}$ \\
\hline $\begin{array}{l}\text { BLACK } \\
\text { WIDOW }\end{array}$ & ATHENA & $\begin{array}{l}* \text { Intelligence and } \\
\text { battle strategies are } \\
\text { similar. } \\
* \text { They reflect } \\
\text { women's war. } \\
* \text { They never marry } \\
\text { and have no children. }\end{array}$ & $\begin{array}{l}* \text { Black Widow } \\
\text { is not a } \\
\text { superhero, but } \\
\text { Athena is } \\
\text { always a god. }\end{array}$ \\
\hline $\begin{array}{l}\text { CAPTAIN } \\
\text { AMERICA }\end{array}$ & PERSEUS & $\begin{array}{l}* \text { They are beings } \\
\text { living in the name of } \\
\text { brave and humanity. } \\
* \text { Red Skull and } \\
\text { Medusa } \\
* \text { They use shields. } \\
\text { * Special powers are } \\
\text { not innate. }\end{array}$ & $\begin{array}{l}\text { * Captain } \\
\text { America takes a } \\
\text { super powerful } \\
\text { medicine. } \\
\text { * Purpose; } \\
\text { Destroying Red } \\
\text { Skull. } \\
\text { * Perseus takes } \\
\text { his special } \\
\text { powers from } \\
\text { other gods. } \\
\text { * Purpose; Take } \\
\text { Medusa's head }\end{array}$ \\
\hline HAWKEYE & $\begin{array}{l}\text { APOLLON } \\
\text { ARTEMIS }\end{array}$ & $\begin{array}{l}\text { Apollon- Bow and } \\
\text { arrow } \\
* \text { Both can be } \\
\text { considered handsome. } \\
\text { Artemis- Arrow }\end{array}$ & \\
\hline HULK & $\begin{array}{l}\text { HADES } \\
\text { HERKULES }\end{array}$ & $\begin{array}{l}\text { Hades-turned } \\
\text { monster when angry } \\
\text { Hades and Hulk are } \\
\text { famous for being } \\
\text { angry. } \\
\text { Hercules - The } \\
\text { childhood passed } \\
\text { badly. } \\
* \text { The family they } \\
\text { both build is damaged } \\
\text { by their surroundings. }\end{array}$ & $\begin{array}{l}\text { * Hercules and } \\
\text { Hulk work in } \\
\text { harmony with } \\
\text { the team. } \\
\text { Their purpose is } \\
\text { usually to help } \\
\text { others. } \\
\text { * Hercules is } \\
\text { born mortal, but } \\
\text { afterwards he } \\
\text { ascends to } \\
\text { Mount } \\
\text { Olympos, but } \\
\text { the Hulk is } \\
\text { always a mortal } \\
\text { one. }\end{array}$ \\
\hline
\end{tabular}




\begin{tabular}{|c|c|c|c|}
\hline IRON MAN & HEPHAESTUS & $\begin{array}{l}\text { *Iron } \\
\text { *Women entering } \\
\text { their lives }\end{array}$ & $\begin{array}{l}\text { *Physical } \\
\text { appearance }\end{array}$ \\
\hline LOKI & LOKI & $\begin{array}{l}\text { * Thor's brother. } \\
\text { * Odin never admits } \\
\text { him. } \\
\text { *Loki is pretty } \\
\text { jealous of Thor. }\end{array}$ & $\begin{array}{l}\text { * Looks like a } \\
\text { biological sister } \\
\text { with Thor. }\end{array}$ \\
\hline $\begin{array}{l}\text { NICK } \\
\text { FURY }\end{array}$ & ORACLE CALCHAS & $\begin{array}{l}\text { *Creation of a team } \\
\text { against the war } \\
\text { waiting for humanity } \\
* \text { Do not have any } \\
\text { superpowers }\end{array}$ & \\
\hline THOR & THOR & $\begin{array}{l}* \text { The son of Odin } \\
\text { and the prince of } \\
\text { Asgard. } \\
* \text { Trained in martial } \\
\text { arts. } \\
* \text { The magic hammer } \\
\text { Mjolnir is his } \\
\text { weapon. }\end{array}$ & $\begin{array}{l}\text { * Super hero } \\
\text { Thor; Blonde, } \\
\text { blue eyes, beard } \\
\text { shaved. } \\
\text { * You do not } \\
\text { need a magic } \\
\text { glove to use } \\
\text { Mjolnir. } \\
\text { * Can fly with } \\
\text { Mjolnir. } \\
\text { * God never } \\
\text { sent Thor to his } \\
\text { father. } \\
\text { * God is } \\
\text { married to Thor } \\
\text { Goddess Sif, } \\
\text { superhero Thor } \\
\text { is in love with } \\
\text { Jane Foster. }\end{array}$ \\
\hline
\end{tabular}

Table 1: Similarities / differences of superheroes with gods and goddesses (interpreted and compiled by authors) 